\title{
Investigation of Pre-School Children's Perception of Teacher in Their Drawings
}

\author{
Oğuz Serdar Kesicioglu1, Umit Deniz ${ }^{2}$ \\ ${ }^{1}$ Department of Early Child Education, Faculty of Education, Giresun University, Giresun, Turkey \\ ${ }^{2}$ Department of Early Child Education, Faculty of Gazi Education, Gazi University, Ankara, Turkey \\ Email: kesiciogluserdar@gmail.com, sea edu2003@yahoo.com
}

Received 3 March 2014; revised 3 April 2014; accepted 10 April 2014

Copyright (C) 2014 by authors and Scientific Research Publishing Inc.

This work is licensed under the Creative Commons Attribution International License (CC BY).

http://creativecommons.org/licenses/by/4.0/

c) (i) Open Access

\begin{abstract}
This study aims to investigate pre-school children's perception of teacher in their drawings. The research group consists of 226 students in pre-school education institutions within city centers of Ankara and Giresun Provinces. Teacher drawings that children drew by instruction were analyzed with the Draw a Scientist Test-DAST which was developed by Chambers (1983) and consists of 13 categories and six sub-categories. In drawings of children included in this study, no drawings were found related to 3 categories; hence, only the drawings in other categories were assessed. The presence of sub-categories in each category was taken into account while coding. The frequencies and percentages obtained via descriptive statistics were presented on tables. According to the findings, majority of the children generally give place to positive properties in their drawings.
\end{abstract}

\section{Keywords}

Preschool, Teacher, Perception

\section{Introduction}

Early childhood years have a unique and special place in every human-related science field with unique developmental features. Children in this period show differences that are incomparable with adults in many fields such as science, mathematics, art etc.; learning and exhibiting what they learn. Children can make definable drawings after the age of four. In general, the first definable and most important figure in children's drawings is human. Human figure drawings emerge as a result of the fact that children investigate, recognize, research about humans around them and develop ideas about these humans. Apart from the human figure, children describe the most attractive things in their drawings (Artut, 2004; Öncü \& Darıca, 2004; Koppitz, 1984). Their drawings are mostly instinctive and do not have any aesthetic concern. Artistic activities and drawings are the most important 
communicative instrument and process for little children having limited cognitive and verbal experience (Artut, 2004). Drawing enables children to feel relaxed, recognize their environment and prove themselves (Artut, 2004). It also contributes to develop many skills such as improving academic skills, developing a tolerance and expressing feelings (Erden, 2012; Poyraz \& Dere, 2003; Wardle, 2003).

Drawing is a more efficient way than verbal expression to express events that affect children emotionally (Beytut et al., 2009). Children represent many different factors and experiences in their drawings. They see the world the way they perceive it. Their perceptions are represented on drawings in a more powerful way (Malchiodi, 1998; Yavuzer, 1986). Their ideas, thoughts, feelings and excitements about events and things are revealed through their drawings (Gürtuna, 2003; Malchiodi, 1998; Yavuzer, 1986). They can express the ideas and thoughts of others through drawing (Artut, 2004). These characteristics of children enable us to have information about their ideas, thoughts and inner worlds through their drawings (Malchiodi, 1998; Yavuzer, 1986).

In early years, children can realize themselves in an environment where they are appreciated, loved and supported. Pre-school teachers have a great role in the formation of such an environment (MEB, 2013). Children get out of the family environment at the beginning of pre-school education. Children who leave the house for the first time start to spend most time of the day with new friends and adults. They mostly connect with their teacher in school (Margetts, 2003; Oktay \& Unutkan, 2005). For that reason, one of the most important factors that affect success and efficiency in pre-school education is teacher (Alkan, 2003). No matter how successfully the curricula are designed, it is not possible to reach the targets in children development unless teachers who are the appliers of these curricula are competent (Kumral, 2009).

Relationships between children and teacher that lay the basis for learning and education result in a positive or negative learning environment in classroom (Ergün \& Duman, 1998). In early childhood period when the model learning is very effective, children are impressed by their teacher's behaviors (Oral, 1997). The teacher affects children with his/her personality and s/he is assessed by his/her positive or negative behaviors and attitudes (Kılıç et al., 2004). A special connection should be built between teacher and child for an effective education (Çetin, 2001). Children model themselves on their teachers through their appearance, communication and behaviors. They are very sensitive to physical messages of teachers. If physical messages contradict with the verbal messages, trust decreases and the positive effect of teacher weakens (Gordon, 1999). For that reason, teacher drawings of pre-school students and the function of metaphors they use may give us some important clues about the perception of teacher (Aytaç, 2012). A good analysis of these clues may improve the education quality. Similarly, Harrison et al. (2007) emphasize that children's teacher drawings and teacher-child interaction may show significant emotional clues and also it would be easier for children to reflect their negative, challenging and harsh feelings through drawing rather than stating them directly.

Taking stand from these reasons, this study was conducted to assess the reflections of the education given by pre-school teachers, who have a significant effect on children, on their drawings and to bring contribution in pre-school education field by assessing the obtained data for the development of both teachers and children.

\section{Methodology}

\subsection{Research Model}

Phenomenology model was used to reveal pre-school children's perception of teacher in their drawings in this study designed qualitatively. A qualitative process was used to reveal the perceptions and events in natural environment with a realistic and holistic manner (Yıldırım \& Şimşek, 2008). Phenomenology consists of the description of conscious experience of a person about a phenomenon (Christensen, Johnson, \& Turner, 2011). One of the ways to assess children's expression in various aspects is to make sense out of symbols through various dimensions and to bring a more holistic point of view to the drawing expression of children as an audience. "Looking with a phenomenological eye" refers to the recognition and expectation of the fact that each child approaches to a drawing in a different way, they have a unique drawing style with favorite or hated compositions, shapes, colors. In the analysis of the children's drawings, the important phenomenological point is to emphasize the various meanings, created context and the world view of the drawer (Malchiodi, 2005).

\subsection{Research Group}

The research group consists of 266 pre-school students randomly selected from Ankara and Giresun City Cen- 
ters. "Easily accessible condition sampling” was used to define the sample. For that reason, easily accessible children who still take education in kindergarten were included in this study. Of the all children included in the study, 104 are female and 162 are male. All of the children are aged between 68 - 60 months.

\subsection{Data Collection}

Before giving a start to data collection, a conversation was opened with students included in the sampling about their teachers. Afterwards, the instruction of "I want you to draw your teacher" was given and children were asked to draw. Crayons, white A4 paper were given to students and they were allowed to draw as long as they wished. No intervention was made to children's drawings and no guidance was offered. Then, each child was asked to talk about his/her drawing and what they told were recorded behind the drawing.

\subsection{Data Collection Instrument}

\section{Draw a Scientist Test-DAST}

"Draw a Scientist Test-DAST" analysis method developed by Chamber (1983) divides the image of the typical scientist into seven characteristics. Finson and Beaver (1995) developed this measure as Draw a Scientist TestChecklist-DAST-C which is easily accessible by anyone. In this study, "Teacher Perception Checklist" developed by Aykaç (2012) with 13 categories and six sub-categories in line with the specialist views on "Draw a Scientist" test was used. However, only 10 categories were used in the analysis of drawings, as no data were obtained related to other 3 categories. The categories used in this study are as follows:

1) Children's perception of teacher (human, a familiar person, cartoon character, object and other).

2) Children's sexual perception of teacher (female, male, non-human, vague etc.).

3) Physical appearance (in-a-suit, wearing tie, in-a-sweatsuit, messy, young etc.).

4) Size (bigger than the actual size, smaller than the actual size, realistic).

5) Gesture and mimics (smiling, excited, surprised, puzzled, angry, upset, shy, concerned, unhappy, thoughtful etc.).

6) Physical properties (with glasses, messy hair, clean, well-groomed, bald, bearded, mustached, physically disabled, having remarkable scars etc.).

7) Place (classroom, in front of/next to the board, table, laboratory, teachers' room, country, school garden, ceremony activity, at computer, next to the flag, in the sky etc.).

8) Action (writing on the board, talking to students, reading papers, reading book, giving lecture, resting, making experiment, using violence on students, loving students, at an activity etc.).

9) Objects in the hand (ruler-stick, chalk, book, bag, paper, flower, pen, ball), objects in the environment (bookshelf, students, table, board, tree, flower, heart etc.).

10) Objects and things in the classroom (board, table, desk, locker, computer, projector etc.).

\subsection{Data Analyses}

The data obtained in this research were analyzed by the code list; percentage and frequency values were used to interpret these findings. As multiple data were obtained from one drawing in some categories, the frequency values are higher in Table 2, Table 5 and Table 9 compared to the research group. The data were compared in order to improve the reliability and validity of the research. For that reason, researchers investigated drawings one by one and created common themes (Miles \& Huberman, 1994).

\section{Finding}

The findings of this study which was conducted in order to investigate pre-school children's perception of teacher in their drawings were investigated in the categories of children's drawings of their teacher as human or any other thing, gender, physical appearance, size, gesture and mimics, physical properties, location, action type, objects in the hand, objects in the environment within the drawing and were presented on tables with descriptive statistics. All of the children (266) drew their teacher as "human". In the study conducted with 1000 elementary school students, Aykaç (2012) found that majority of the students perceive their teachers as "human" and the minority of them perceive teachers as a prominent personality such as "Atatürk" or objects such as sun, flower, heart, book etc. As there was no drawing related to the "seating arrangement" category, this category 
was not included in the findings.

Table 1 indicates the gender distribution of teachers in children's drawings. 38.7\% of children drew their teachers as "Male" while $49.2 \%$ drew as "Female" drew as $12.1 \%$ "Vague". Most of the children drew their teachers as female. It should not be ignored that the ratio of those who drew as male is also high. This result indicates that the number of male teachers increases in pre-school education and students' traditional gender perception of the teaching profession starts to change and/or their drawings cannot be completely accurate at this period. In his study, Aytaç (2012) found that $62 \%$ of students drew their teachers as "Female". It was found that this result can be related to the high number of female teachers at schools. On the other hand, Keskin (2007) reported that boys tend to draw male and girls tend to draw female children in their drawings.

According to Table 2, the physical appearance of teachers was drawn as "Young" by $49.1 \%$, "In-suit" by $18.9 \%$, "With high-heels" by $8.5 \%$, "Stylish (with accessories)" by $6.8 \%$, "Wearing glasses" by $1.8 \%$ and "No remarkable property" by $14.6 \%$ of the children. In parallel with the findings of the present study, Keskin (2007) reported that around the age of five years, children start to add accessories in human drawings. Children start to add clothes to the body and accessories to the head such as hat etc. According to these findings, we can say that pre-school children pay attention to clothing style of teachers.

As can be seen in Table 3, the size of teacher figures in children's drawings was drawn as "Big" by $44.3 \%$, "Realistic" by $37.6 \%$ and "Small" by $18.1 \%$ of the children. The bigger size of teachers than the actual size in children's drawings can be resulted from the children's perception of teacher as an authority in this period. This result can be related to the fact that children's perception of ratio is not well developed yet and this fact reflects on their drawings in developmental terms. Aykaç (2012) reported that big size of teacher figure in children's drawings represents the value attached to the teacher by children. Similarly, Papadakis-Michaelides (1989) and Payne (1990) reported that children tend to draw persons who they deem to be powerful in bigger sizes.

In Table 4, it was found that the gestures and mimics of teachers were drawn as "Smiling-happy" by $62.4 \%$, "Unhappy" by $20.3 \%$, "Angry" by $3.1 \%$, "Vague" by $25.6 \%$ of the children. According to these findings, we can say that children reflect their teachers mostly as "Smiling". According to the literature, the most natural reflection way of children to represent their attitudes and feelings are their drawings (Yaşar \& Aral, 2009; Harrison, Clarke, \& Ungerer, 2007; Fury, 2007; Yavuzer, 2007; Carlson \& Sroufe, 1997). As can be seen in these findings, most of the children clearly reflect that they have a positive attitude towards teacher.

According to Table 5, physical properties of teachers were drawn as "With long body" by 25.9\%, "With long arm/hand" by $19.3 \%$, "With messy hair" by $17.8 \%$, "With long hair" by $11.5 \%$, "With bald" by $8.9 \%$, "With beard" by $2.9 \%$, "No remarkable property" by $13.7 \%$ of the children. Baysal (2010) reported that pre-school children use body proportions without any perspective concern and scale in their drawings. In parallel with the findings

Table 1. Gender of the teacher in children's drawings.

\begin{tabular}{cccccccccc}
\hline & Male & \multicolumn{3}{c}{ Female } & \multicolumn{2}{c}{ Vague } & \multicolumn{3}{c}{ Total } \\
\hline $\mathrm{f}$ & $\%$ & $\mathrm{f}$ & $\%$ & $\mathrm{f}$ & $\%$ & $\mathrm{f}$ & $\%$ \\
\hline 103 & 38.7 & 131 & 49.2 & 32 & 12.1 & 266 & 100 \\
\hline
\end{tabular}

Table 2. Physical appearance of the teacher in children's drawings.

\begin{tabular}{ccccccccccccccc}
\hline \multicolumn{2}{c}{ Young } & \multicolumn{2}{c}{ In-suit } & \multicolumn{2}{c}{ With high-heels } & \multicolumn{2}{c}{$\begin{array}{c}\text { Stylish (earrings, } \\
\text { hairpin etc.) }\end{array}$} & Wearing glasses & \multicolumn{2}{c}{$\begin{array}{c}\text { No remarkable } \\
\text { property }\end{array}$} & Total \\
\hline $\mathrm{f}$ & $\%$ & $\mathrm{f}$ & $\%$ & $\mathrm{f}$ & $\%$ & $\mathrm{f}$ & $\%$ & $\mathrm{f}$ & $\%$ & $\mathrm{f}$ & $\%$ & $\mathrm{f}$ & $\%$ \\
\hline 138 & 49.1 & 53 & 18.9 & 24 & 8.5 & 19 & 6.8 & 5 & 1.8 & 41 & 14.6 & 280 & 100 \\
\hline
\end{tabular}

Table 3. Size of the teacher figure in children's drawings.

\begin{tabular}{|c|c|c|c|c|c|c|c|}
\hline \multicolumn{2}{|c|}{ Big } & \multicolumn{2}{|c|}{ Realistic } & \multicolumn{2}{|c|}{ Small } & \multicolumn{2}{|c|}{ Total } \\
\hline $\mathrm{f}$ & $\%$ & $\mathrm{f}$ & $\%$ & $\mathrm{f}$ & $\%$ & $\mathrm{f}$ & $\%$ \\
\hline 118 & 44.3 & 100 & 37.6 & 48 & 18.1 & 266 & 100 \\
\hline
\end{tabular}


Table 4. Gestures and mimics of the teacher in children's drawings.

\begin{tabular}{ccccccccccc}
\hline \multicolumn{2}{c}{ Smiling-happy } & \multicolumn{2}{c}{ Unhappy } & \multicolumn{2}{c}{ Angry } & \multicolumn{3}{c}{ Vague } & \multicolumn{3}{c}{ Total } \\
\hline $\mathrm{f}$ & $\%$ & $\mathrm{f}$ & $\%$ & $\mathrm{f}$ & $\%$ & $\mathrm{f}$ & $\%$ & $\mathrm{f}$ & $\%$ \\
\hline 166 & 62.4 & 54 & 20.3 & 8 & 3.1 & 68 & 25.6 & 266 & 100 \\
\hline
\end{tabular}

Table 5. Physical properties of the teacher in children’s drawings.

\begin{tabular}{|c|c|c|c|c|c|c|c|c|c|c|c|c|c|c|c|}
\hline \multicolumn{2}{|c|}{ Long body } & \multicolumn{2}{|c|}{ Long arm/hand } & \multicolumn{2}{|c|}{ Messy hair } & \multicolumn{2}{|c|}{ Long hair } & \multicolumn{2}{|c|}{ Bald } & \multicolumn{2}{|c|}{ Beard } & \multicolumn{2}{|c|}{$\begin{array}{l}\text { No remarkable } \\
\text { property }\end{array}$} & \multicolumn{2}{|c|}{ Total } \\
\hline $\mathrm{f}$ & $\%$ & $\mathrm{f}$ & $\%$ & $\mathrm{f}$ & $\%$ & $\mathrm{f}$ & $\%$ & $\mathrm{f}$ & $\%$ & $\mathrm{f}$ & $\%$ & f & $\%$ & $\mathrm{f}$ & $\%$ \\
\hline 70 & 25.9 & 52 & 19.3 & 48 & 17.8 & 31 & 11.5 & 24 & 8.9 & 8 & 2.9 & 37 & 13.7 & 270 & 100 \\
\hline
\end{tabular}

of the research, Buyurgan and Buyurgan (2001) reported that pre-school children tend to draw body ratios of human figures without proportion and draw some parts of the body bigger than the others. Similarly, Yavuzer (2007) reported that the non-proportional and unrealistic body ratios are normal developmental indicators for pre-school children at pre-schema stage. On the other hand, Roland (1995) reported that bigger size of a figure in children's drawings is an indicator of the fact that pre-school period children aim to bring some motion to that figure. A child may draw big feet to make the human figure walk.

In Table 6, the place of the teacher was drawn as "Playing” by 39.8\%, "Space” by 30.5\%, "Sky" by 16.2\%, "Country" by $7.9 \%$ and "School garden" by $6.6 \%$ of the children. According to these findings, the playing teacher drawings are more than the other places. This situation makes us think that children take part in activities with their teachers and have positive feelings; also indicates that the child is positively affected by the environment where s/he takes place. In parallel with these findings, Özer (2008) reported that children at the age group of 5 - 6 years have less developed drawing results from "Draw a Scientist" test in public schools compared to the results of those in private school. It is reported that this effect results from the opportunities of being stimulated and taking place in enriched environments in pre-school period rather than the school and education quality at school.

Table 7 indicates that, action type of teachers was drawn as "Playing/performing an activity" by 43.2\%, "Standing” by $24.4 \%$, "Not-drawn” by $32.3 \%$ of the children. According to these findings, we can say that preschool children perceive their teachers as an active and enjoyable person and thus have a positive attitude. The fact that children did not give any place to seating arrangement in their drawings can be related to the lack of a single arrangement in pre-school education and the central role of motion and playing in education. However, it should be remembered that pre-school period children cannot give place to all details of a person, event or environment in this drawings.

According to Table $\mathbf{8 , 7 7 . 8 \%}$ of the children drew their teachers without any object in their hands. Objects in the hand of the teacher were drawn as "Ball" by 10.5\%, "Flower" by 14\%, "Balloon" by $4.5 \%$ and "Stick" by $1.9 \%$, "Not drawn" by $77.8 \%$ of the children. According to these findings, we can see that pre-school children draw their teachers with positive objects. This situation makes us think that children have a positive attitude towards their children. Aykaç (2012) found that elementary-school students generally draw their teachers giving lecture next to the board with the chalk in the hand.

As can be seen in Table 9, the objects around the teacher were drawn as "Child” by 31.7\%, "Sun” by 22.8\%, "Flower/tree” by 17.6\%, "Cloud” by 7.2\%, “Animals” by 4.9\%, "Building” by 2.9\% of the children. According to these findings, most of the pre-school students draw themselves next to the teacher and show that they are happy to be with their teachers. The drawings of objects such as sun, flower etc. support the idea that children have a positive perception of the teacher. Baysal (2010) reported that pre-school children use tree, flower and animal figures in their drawings and most of them draw sun as well.

\section{Conclusion and Recommendations}

In this study conducted in order to investigate the pre-school students' perception of teacher in their drawings, all of the children drew their teachers as human. In most of the drawings, teacher was drawn as a young, tall and 
Table 6. Place of the teacher in children's drawings.

\begin{tabular}{ccccccccccccc}
\hline \multicolumn{2}{c}{ Playing } & \multicolumn{2}{c}{ Space } & \multicolumn{2}{c}{ Sky } & \multicolumn{2}{c}{ Country } & \multicolumn{2}{c}{ School garden } & \multicolumn{2}{c}{ Total } \\
\hline $\mathrm{f}$ & $\%$ & $\mathrm{f}$ & $\%$ & $\mathrm{f}$ & $\%$ & $\mathrm{f}$ & $\%$ & $\mathrm{f}$ & $\%$ & $\mathrm{f}$ & $\%$ \\
\hline 106 & 39.8 & 81 & 30.5 & 43 & 16.2 & 21 & 7.9 & 15 & 6.6 & 266 & 100 \\
\hline
\end{tabular}

Table 7. Action type of the teacher in children's drawings.

\begin{tabular}{ccccccccc}
\hline \multicolumn{2}{c}{ Playing/performing an activity } & \multicolumn{2}{c}{ Standing } & \multicolumn{2}{c}{ Not-drawn } & \multicolumn{3}{c}{ Total } \\
\hline $\mathrm{f}$ & $\%$ & $\mathrm{f}$ & $\%$ & $\mathrm{f}$ & $\%$ & $\mathrm{f}$ & $\%$ \\
\hline 115 & 43.2 & 65 & 24.4 & 86 & 32.3 & 266 & 100 \\
\hline
\end{tabular}

Table 8. Objects in the hand of the teacher in children's drawings.

\begin{tabular}{ccccccccccccc}
\hline & \multicolumn{2}{c}{ Ball } & \multicolumn{2}{c}{ Flower } & \multicolumn{2}{c}{ Balloon } & \multicolumn{2}{c}{ Stick } & \multicolumn{2}{c}{ Not-Drawn } & \multicolumn{3}{c}{ Total } \\
$\mathrm{f}$ & $\%$ & $\mathrm{f}$ & $\%$ & $\mathrm{f}$ & $\%$ & $\mathrm{f}$ & $\%$ & $\mathrm{f}$ & $\%$ & $\mathrm{f}$ & $\%$ \\
\hline 28 & 10.5 & 14 & 5.2 & 12 & 4.5 & 5 & 1.9 & 207 & 77.8 & 266 & 100 \\
\hline
\end{tabular}

Table 9. Objects around the teacher in children’s drawings.

\begin{tabular}{ccccccccccccccccc}
\hline \multicolumn{2}{c}{ Child } & \multicolumn{2}{c}{ Sun } & \multicolumn{2}{c}{ Flower/tree } & \multicolumn{2}{c}{ Cloud } & \multicolumn{2}{c}{ Animals } & \multicolumn{2}{c}{ Building } & \multicolumn{2}{c}{ Not-drawn } & \multicolumn{2}{c}{ Total } \\
\hline $\mathrm{f}$ & $\%$ & $\mathrm{f}$ & $\%$ & $\mathrm{f}$ & $\%$ & $\mathrm{f}$ & $\%$ & $\mathrm{f}$ & $\%$ & $\mathrm{f}$ & $\%$ & $\mathrm{f}$ & $\%$ & $\mathrm{f}$ & $\%$ \\
\hline 92 & 31.7 & 66 & 22.8 & 51 & 17.6 & 21 & 7.2 & 14 & 4.9 & 8 & 2.9 & 38 & 13.1 & 290 & 100 \\
\hline
\end{tabular}

female. Majority of the children drew their teachers with the child, playing, with a ball in hand and they did not give any place to seating arrangement of the classroom.

Drawing activities of children are indispensably important activities for their development, creativeness and self-expression. For that reason, the drawings of children are used to define their feelings and thoughts, support them in all development fields and evaluate them and their education. However, the assessment of sole drawings for the evaluation of children and their education is not sufficient to reach accurate results. This situation can be related to the fact that the development of children is dynamic, their creativeness merges with their imagination and their activities are more important than the products during the activity. In addition, the reflections of pre-school children's interaction with the environment are available in their activities and products related to the education. Therefore, in line with the findings obtained from this study, we can emphasize that all teachers should be more planned and professional in education environment in order to improve all children's positive perception of teacher.

\section{References}

Alkan, C. (2003). Öğretmenlik mesleğine girişs (Ed. V. Sönmez). Ankara: Anı Yayıncılık.

Artut, K. (2004). Okul öncesinde resim ĕgitimi. Ankara: Anı Yayıncılık.

Aytaç, N. (2012). İlköğretim öğrencilerinin resimlerinde öğretmen ve öğrenme süreci algıs1. Eğitim ve Bilim, 37, $298-315$.

Baysal, M. (2010). 1-10 Yaş Arası Çocukların 1-11 yaş çocuk resimlerinde renk, biçim ve konuların Tablelandırılması

(Yayımlanmamış yüksek lisans tezi). Kütahya: Dumlupınar Üniversitesi Sosyal Bilimler Enstitüsü Resim Ana Sanat Dalı.

Beytut, D. Ş., Bolışık, B., Solak, U., \& Seyfioğlu, U. (2009). Çocuklarda hastaneye yatma etkilerinin projektif yöntem olan resim çizme yoluyla incelenmesi. Maltepe Üniversitesi Hemşirelik Bilim ve Sanatı e-Dergisi, 2, 35-44.

Buyurgan, S., \& Buyurgan, U. (2001). Sanat eğitimi ve öğretimi. Ankara: Dersal Yayıncılık.

Çetin, Ş. (2001). İdeal öğretmen üzerine bir araştırma. Milli Eğitim Dergisi, 149, 29-37.

Christensen, B. L., Johnson, R. B., \& Turner, L. A. (2011). Research Methods, Design and Analysis. Boston: Pearson.

Erden, Ş. (2009). Okul öncesi dönemde sanat etkinliklerinin önemi ve sanat köşesi. Aile ve çocuk (pp. 361-371). Ankara: 
Ankara Üniversitesi Basımevi.

Ergün, M., \& Duman, T. (1998). Kritik durumlarda öğretmen davranışları. Millî Eğitim Dergisi, 137, 45.

Fury, G., Carlson, E. A., \& Sroufe, L. A. (1997). Children’s Representations of Attachment Relationships in Family Drawings. Child Development, 68, 1154-1164. http://dx.doi.org/10.2307/1132298

Gordon, T. (1999). Etkili öğretmenlik eğitimi (Çev. E. Aksay). İstanbul: Sistem Yayıncılık.

Gürtuna, S. (2003). Çocuk ve sanat eğitimi “Çocuğum sanatla tanışıyor”. İstanbul: Morpa Yayınları.

Harrison, L. J., Clarke, L., \& Ungerer, J. A. (2007). Children’s Drawings Provide a New Perspective on Teacher-Child Relationship Quality and School Adjustment. Early Childhood Research Quarterly, 22, 55-71. http://dx.doi.org/10.1016/j.ecresq.2006.10.003

Keskin, S. P. (2007). Çocuk çizgilerindeki giz çöp çocuk (İkinci Bask1). İstanbul: Boyut Yayınları.

Kılıç, M., Kaya, A., Yıldırım, N., \& Genç, G. (2004). Eğitimci gözüyle öğretmen ve öğrenci. XIII. Ulusal Eğitim Bilimleri Kurultayı, 6-9 Temmuz, İnönü Üniversitesi, Eğitim Fakültesi, Malatya.

Koppitz, E. M. (1984). Psychological Evaluation of Human Figure Drawings by Middle School Pupils. New York: Harcourt Brace Jovanovich.

Kumral, O. (2009). Öğretmen adaylarının öğretim elemanlarının davranışlarına yönelik algıları. Pamukkale Üniversitesi Ĕ̈itim Fakültesi Dergisi, 1, 92-102.

Malchiodi, C. A. (2005). Çocukların Resimlerini Anlamak (Yurtbay, T. Çev.). İstanbul: Epsilon Yayınları.

Margetts, K. (2003). Personal, Family and Social Influences on Children’s Early School Adjustment. Paper Presented at the AECA Biennial Conference, Hobart, 10-13 July.

Miles, M. B., \& Huberman, A. M. (1994). An Expanded Source Book Qualitative Data Analysis (2nd Edition). California: Sage Pablications, Inc.

Oktay, A., \& Unutkan, Ö. P. (2005). Erken çocuklukta gelişim ve eğitimde yeni yaklaşımlar (Editor: Müzeyyen Sevinç), İlköğretime hazır oluş ve okul öncesi eğitimle ilköğretimin karşılaştırılması, Morpa Kültür Yayınları, İstanbul, 145-155.

Öncü, E. Ç. (2004). Beş-altı yaş grubu korunmaya muhtaç çocukların insan figürü çizimlerine göre sanat eğitiminin etkisinin incelenmesi. Erken Çocukluk Ĕgitiminde Sanat Sempozyumu, Ankara, 2-3 Aralık.

Oral, B. (1997). Öğretmen adaylarının öğretmenlik uygulamasına ilişkin görüşleri. Çağdaş Ĕgitim Dergisi, Sayı: 232 Mayıs.

Özer, S. (2008). Bir insan çiz testinde çocukların performanslarında cinsiyet ve sosyal etkiler. XV. Ulusal Psikoloji Kongresi.

Papadakis-Michaelides, E. (1989). Development of Children's Drawings in Relation to Gender and Culture. Unpublished Ph.D. Thesis, Birmingham: University of Birmingham.

Payne, M. A. (1990). Effects of Parental Presence/Absence on Size of Children’s Human Figüre Drawings. Perceptual and Motor Skills, 70, 843-849. http://dx.doi.org/10.2466/pms.1990.70.3.843

Poyraz, H., \& Dere, H. (2003). Okul öncesi eğitimin ilke ve yöntemleri. Ankara: Anı Yayıncılık.

Roland, G. (1995). Art Encounters. USA: University of Florida.

Wardle, F. (2003). Introduction to Early Childhood Education. USA: Allyn and Bacon.

Yaşar, C. M., \& Aral, N. (2009). Sanat ürünü olarak çocuk resimleri. Çăğdaş Eğitim Dergisi, 34, 24-31.

Yavuzer, H. (2003). Resimleriyle çocuk, resimleriyle çocuğu tanıma (10. Basım). İstanbul: Remzi Kitabevi.

Yavuzer, H. (2012). Resimleriyle çocuk (12. Bask1). İstanbul: Remzi Kitapevi.

Yıldırım, A., \& Şimşek, H. (2008). Sosyal bilimlerde nitel araştırma yöntemleri. Ankara: Seçkin Yayınları. 


\section{Appendix}

\section{Teacher Perception Checklist (10 categories)}

1) Children's perception of teacher (human, a familiar person, cartoon character, object and other).

2) Children's sexual perception of teacher (female, male, non-human, vague etc.).

3) Physical appearance (in-a-suit, wearing tie, in-a-sweatsuit, messy, young etc.).

4) Size (bigger than the actual size, smaller than the actual size, realistic).

5) Gesture and mimics (smiling, excited, surprised, puzzled, angry, upset, shy, concerned, unhappy, thoughtful etc.).

6) Physical properties (with glasses, messy hair, clean, well-groomed, bald, bearded, mustached, physically disabled, having remarkable scars etc.).

7) Place (classroom, in front of/next to the board, table, laboratory, teachers' room, country, school garden, ceremony activity, at computer, next to the flag, in the sky etc.).

8) Action (writing on the board, talking to students, reading papers, reading book, giving lecture, resting, making experiment, using violence on students, loving students, at an activity etc.).

9) Objects in the hand (ruler-stick, chalk, book, bag, paper, flower, pen, ball), Objects in the environment (bookshelf, students, table, board, tree, flower, heart etc.).

10) Objects and things in the classroom (board, table, desk, locker, computer, projector etc.). 